\title{
Methods to determine the relative value of genetic traits in dairy cows to reduce greenhouse gas emissions along the chain
}

\author{
C. E. van Middelaar, ${ }^{* 1}$ P. B. M. Berentsen, $\dagger$ J. Dijkstra, $\ddagger$ J. A. M. van Arendonk,§ and I. J. M. de Boer* \\ ${ }^{*}$ Animal Production Systems Group, Wageningen University, PO Box 338, 6700 AH Wageningen, the Netherlands \\ †Business Economics Group, PO Box 8130, 6700 AH Wageningen, the Netherlands \\ $\ddagger$ Animal Nutrition Group, Wageningen University, PO Box 338, $6700 \mathrm{AH}$ Wageningen, the Netherlands \\ §Animal Breeding and Genomics Centre, Wageningen University, PO Box 338, $6700 \mathrm{AH}$ Wageningen, the Netherlands
}

\begin{abstract}
Current decisions on breeding in dairy farming are mainly based on economic values of heritable traits, as earning an income is a primary objective of farmers. Recent literature, however, shows that breeding also has potential to reduce greenhouse gas (GHG) emissions. The objective of this paper was to compare 2 methods to determine GHG values of genetic traits. Method 1 calculates GHG values using the current strategy (i.e., maximizing labor income), whereas method 2 is based on minimizing GHG per kilogram of milk and shows what can be achieved if the breeding results are fully directed at minimizing GHG emissions. A whole-farm optimization model was used to determine results before and after 1 genetic standard deviation improvement (i.e., unit change) of milk yield and longevity. The objective function of the model differed between method 1 and 2. Method 1 maximizes labor income; method 2 minimizes GHG emissions per kilogram of milk while maintaining labor income and total milk production at least at the level before the change in trait. Results show that the full potential of the traits to reduce GHG emissions given the boundaries that were set for income and milk production $(453$ and $441 \mathrm{~kg}$ of $\mathrm{CO}_{2}$ equivalents/unit change per cow per year for milk yield and longevity, respectively) is about twice as high as the reduction based on maximizing labor income (247 and $210 \mathrm{~kg}$ of $\mathrm{CO}_{2}$ equivalents/unit change per cow per year for milk yield and longevity, respectively). The GHG value of milk yield is higher than that of longevity, especially when the focus is on maximizing labor income. Based on a sensitivity analysis, it was shown that including emissions from land use change and using different methods for handling the interaction between milk and meat production can change results, generally in favor of milk yield. Results can be used by breeding organizations that want to
\end{abstract}

Received August 23, 2013.

Accepted April 10, 2014.

${ }^{1}$ Corresponding author: Corina.vanMiddelaar@wur.nl include GHG values in their breeding goal. To verify GHG values, the effect of prices and emissions factors should be considered, as well as the potential effect of variation between farm types.

Key words: life cycle assessment, economic value, milk yield, longevity

\section{INTRODUCTION}

The need for strategies to reduce greenhouse gas (GHG) emissions from human activities, mainly consisting of carbon dioxide $\left(\mathrm{CO}_{2}\right)$, methane $\left(\mathrm{CH}_{4}\right)$, and nitrous oxide $\left(\mathrm{N}_{2} \mathrm{O}\right)$, has been highlighted (IPCC, 2007). Use of fossil fuel and land use change are identified as the primary sources for increased levels of atmospheric $\mathrm{CO}_{2}$, whereas agriculture is identified as the primary source for increased levels of $\mathrm{CH}_{4}$ and $\mathrm{N}_{2} \mathrm{O}$ (IPCC, 2007). The majority of $\mathrm{CH}_{4}$ emissions from agriculture relate to enteric fermentation of ruminants. About half of the total GHG emissions along the dairy production chain are enteric $\mathrm{CH}_{4}$ (Hörtenhuber et al., 2010). To reduce $\mathrm{CH}_{4}$ emissions, different strategies have been proposed; one of these strategies is increasing the productivity and efficiency of the dairy herd by selective breeding (Buddle et al., 2011; De Haas et al., 2011).

Productivity and efficiency can be increased by genetic improvement of traits such as milk yield, feed efficiency, longevity, and calving interval (Bell et al., 2011). Increasing milk yield per cow, for example, reduces $\mathrm{CH}_{4}$ emissions per kilogram of milk by diluting $\mathrm{CH}_{4}$ formed during fermentation of feed related to maintenance (Bannink et al., 2011; Bell et al., 2010, 2011). Bannink et al. (2011) showed that a $33 \%$ increase in production of fat- and protein-corrected milk (FPCM), from 17.2 $\mathrm{kg} / \mathrm{d}$ in 1990 to $22.9 \mathrm{~kg} / \mathrm{d}$ in 2008 , reduced enteric $\mathrm{CH}_{4}$ per kilogram of FPCM by 13\%, from 17.6 to $15.4 \mathrm{~g}$. Increasing longevity reduces $\mathrm{CH}_{4}$ per kilogram of milk by reducing the number of female replacements producing $\mathrm{CH}_{4}$ for maintenance and growth, without producing milk (Garnsworthy, 2004; Wall et al., 2010). Wall et al. 
(2010) showed that increasing longevity from an average of 3.0 to 3.5 lactations can reduce enteric $\mathrm{CH}_{4}$ per kilogram of milk by $4.4 \%$.

Changing a trait, such as milk yield or longevity, however, can affect the whole farm, including feeding strategy, management practices and purchases of inputs, such as concentrate and fertilizer (Bell et al., 2010; Wall et al., 2010). Evaluating the effect of a genetic improvement, therefore, requires modeling the whole farm. Moreover, optimization of farm management before and after a change in trait is required to prevent under- or overestimation of the effect of genetic improvement (Groen et al., 1997). Finally, if the effect concerns GHG emissions, the analysis should include emission along the chain (i.e., from production of farm inputs up to the farm gate) to avoid pollution swapping. By evaluating the effect of one unit change in individual traits on GHG emissions at the chain level, the relative value of each trait to reduce GHG emissions along the chain can be determined. A similar approach is used to calculate the relative economic value of traits (Groen, 1988; Koenen et al., 2000).

Two studies evaluated the effect of improving individual traits in dairy cows on GHG emissions at farm or chain level. Wall et al. (2010) evaluated the effect of increasing longevity on $\mathrm{CH}_{4}$ and $\mathrm{N}_{2} \mathrm{O}$ emissions at farm level, whereas Bell et al. (2011) evaluated the effect of increasing feed efficiency, milk yield, calving interval, and longevity on GHG emissions at the chain level. Both Wall et al. (2010) and Bell et al. (2011), however, did not optimize farm management with changing levels of genetic traits.

Farm management can be optimized based on different objectives, such as maximizing labor income (i.e., the main interest in deriving breeding objectives) or minimizing GHG emissions per unit product. It is not clear how a difference in objective affects the relative value of individual traits to reduce GHG emissions per kilogram of FPCM.

The objective of the current study was to compare 2 methods to determine the relative value of genetic traits in dairy cows to reduce GHG emissions along the milk production chain (i.e., up to the farm gate). Both methods are based on a whole-farm dairy model, use linear programming (LP) to optimize farm management, and include all GHG emissions along the chain, up to the farm gate. The first method is based on maximizing labor income of the farm family; the interrelated consequences for GHG emissions are evaluated as a side-effect. The second method is based on minimizing GHG emissions per kilogram of milk. We compared both methods by assessing the consequences of an increase in milk yield and longevity of cows on an average Dutch dairy farm on sandy soil.

\section{MATERIALS AND METHODS}

The first method is based on the exact same principle that is used to calculate economic values. A dairy farm LP model with the objective to maximize labor income was used to determine the economic benefit per unit change in milk yield and longevity. The effect on GHG emissions (i.e., the GHG value) was considered as a consequence. This method, therefore, shows the effect of economic optimization, which is currently the main interest in deriving breeding objectives, on GHG emissions. The second method uses the same model, but now minimizes GHG emissions per kilogram of milk along the chain (i.e., up to the farm gate), to determine the maximum GHG reduction per unit change in milk yield and longevity while maintaining initial labor income and milk production at the farm level (i.e., before trait improvement). This method, therefore, determines the full potential of a genetic trait to reduce GHG emissions along the chain, given the boundaries that were set for income and milk production. Results might change when reducing GHG emissions yields additional income. At this moment, however, no carbon-pricing scheme exists for agriculture.

\section{Dairy Farm LP Model}

The dairy farm LP model used is based on Berentsen and Giesen (1995). This static year model includes all relevant activities and constraints that are common to Dutch dairy farms, such as on-farm feed production, purchase of feed products, and animal production, including rearing of young stock. The model distinguishes a summer and a winter period regarding feeding. Dietary options include grass from grazing, grass silage, maize silage, and 3 types of concentrates that differ in protein levels (i.e., standard, medium, and high). Nutritional values of the feed ingredients are in Table A1. Available land can be used as grassland or as maize land. Constraints of the model include fixed resources of the farm (e.g., land area, family labor), links between activities (e.g., fertilizer requirements of grass and arable land with available nutrients from manure and purchased fertilizers), and environmental policies [e.g., limits to the application of total mineral nitrogen and phosphate $\left(\mathrm{P}_{2} \mathrm{O}_{5}\right)$ fertilization]. For a more detailed description of the model, see Van Middelaar et al. (2013a).

The central element of the LP model is an average dairy cow from the Holstein Friesian breed with a given milk production and longevity, calving in February, and conditions representing the dairy cattle of the farm. Feed requirements (energy and protein) and intake capacity of this average cow were determined using the bio-economic model of Groen (1988). The same model 
was used to determine herd composition and yearly replacement rate, based on the average longevity of the cow. The replacement rate determines the number of young stock that needs to be kept on the farm for yearly replacement of the dairy cows.

The dairy farm model was adapted to future production circumstances to allow exploration of economic and environmental consequences of selective breeding. The generation interval of dairy cattle was assumed to be 7 yr (CRV, 2012); therefore, production circumstances were defined for 2020. In 2015, the milk quota system will be abolished in the European Union, and therefore no milk quota was assumed. Furthermore, prices of milk components and purchased feed products were adapted based on price prediction for 2020 (Wageningen UR, 2013). Milk price was assumed to be €32.3 per $100 \mathrm{~kg}$ of milk. Price of purchased maize silage was assumed to be $€ 42$ per $t$, and for concentrates was $€ 180$ (standard protein), €208 (medium protein), and $€ 260$ (high protein) per tonne. Grass yield per hectare was increased by $1.5 \%$ per year, based on historical data analysis (Berentsen et al., 1996). In the case of $200 \mathrm{~kg}$ of $\mathrm{N}$ fertilization per ha per year, this implies a grass yield of 72.2 GJ of $\mathrm{NE}_{\mathrm{L}} /$ ha per year in 2020 . The yield of maize silage per hectare was increased by $100 \mathrm{~kg}$ of DM/yr (Rijk et al., 2013), resulting in 108.2 GJ of $\mathrm{NE}_{\mathrm{L}} /$ ha per year in 2020. For the environmental policies, no changes in limits to the application of $\mathrm{N}$ are expected (C. M. Groenestein, Wageningen UR, Wageningen, the Netherlands, personal communication, 2012). Therefore, the annual maximum amount of total mineral N per hectare is $250 \mathrm{~kg}$ for grassland and 140 $\mathrm{kg}$ for maize land, and the annual maximum amount for $\mathrm{N}$ per hectare from animal manure is $250 \mathrm{~kg}$ for farms with at least $70 \%$ grassland and $170 \mathrm{~kg}$ for farms with less than $70 \%$ grassland. Limits to the application of $\mathrm{P}_{2} \mathrm{O}_{5}$ are reduced to an annual maximum of $90 \mathrm{~kg}$ of $\mathrm{P} /$ ha for grassland and $60 \mathrm{~kg}$ of $\mathrm{P} / \mathrm{ha}$ for arable land (based on soils with an average phosphate content), according to the new standards for 2020 (Vierde Nederlands Actieprogramma Nitraatrichtlijn, 2009).

\section{Calculating GHG Emissions}

We used the life cycle assessment (LCA) to calculate emissions of $\mathrm{CO}_{2}, \mathrm{CH}_{4}$, and $\mathrm{N}_{2} \mathrm{O}$ from the different stages along the production chain, up to the moment that milk leaves the farm gate. The LCA is an internationally accepted and standardized method to evaluate the use of resources and emission of pollutants along the chain (Bauman and Tillman, 2004; Rebitzer et al., 2004). Processes included are the extraction of raw materials to produce farm inputs, the manufacturing and distribution of these inputs, and all processes on the dairy farm. Stages related to the transport and processing of milk were assumed to be unaffected by the breeding strategies, and therefore were not included in the analysis. Methods to calculate annual (i.e., recurrent) emissions are described in this section. Methods to calculate nonrecurrent emissions from land use change are described in the sensitivity analysis.

Emissions from the production of synthetic fertilizer, pesticides, tap water, and energy sources (gas, diesel, and electricity) were based on Ecoinvent (2007), from the production of saw dust on Thomassen et al. (2008), and from the production of concentrates and milk replacer on Vellinga et al. (2013). Emissions from production of concentrates include emissions from the production of inputs (e.g., fertilizers, pesticides, machinery, and energy), direct and indirect $\mathrm{N}_{2} \mathrm{O}$ emissions from cultivation, $\mathrm{CO}_{2}$ emissions from liming and urea fertilization, emissions from drying and processing, and emissions from transport in between stages, up to the farm gate. Emission calculations for the production of purchased maize silage were similar to the calculations that were used for on-farm production of maize silage, because purchased maize silage was assumed to be produced in the Netherlands. Similar to on-farm feed production, yield per hectare of purchased feed products (i.e., concentrates and maize silage) were increased by $100 \mathrm{~kg}$ of DM/yr (Rijk et al., 2013), resulting in a decrease in emissions from cultivation per kilogram of ingredient. Emission factors per tonne of purchased concentrate and maize silage are included in Table A2.

Emissions of $\mathrm{CH}_{4}$ from on-farm processes relate to enteric fermentation and to manure management. Enteric $\mathrm{CH}_{4}$ from dairy cows was calculated based on empirical relations between DMI of feed ingredients and $\mathrm{CH}_{4}$ emission factors per ingredient. The $\mathrm{CH}_{4}$ emission factors per feed ingredient were based on Vellinga et al. (2013) and are included in Table A2. For young stock, enteric $\mathrm{CH}_{4}$ emission was based on Intergovernmental Panel on Climate Change (IPCC) Tier 2 methods and default values (i.e., the average gross energy content of feed is assumed to be $18.45 \mathrm{MJ} / \mathrm{kg}$ of $\mathrm{DM}$, and $6.5 \%$ of the gross energy intake is converted to $\mathrm{CH}_{4}$; IPCC, 2006). Emissions of $\mathrm{CH}_{4}$ from manure management were based on national inventory reports (i.e., $0.746 \mathrm{~kg}$ of $\mathrm{CH}_{4} / \mathrm{t}$ of manure produced in stables, and $0.110 \mathrm{~kg}$ of $\mathrm{CH}_{4} / \mathrm{t}$ of manure produced during grazing; De Mol and Hilhorst, 2003).

Emissions of $\mathrm{CO}_{2}$ from on-farm processes related to the combustion of diesel and gas were based on Ecoinvent (2007). Emissions of $\mathrm{N}_{2} \mathrm{O}$ from on-farm processes include both direct and indirect $\mathrm{N}_{2} \mathrm{O}$ from manure management and from $\mathrm{N}$ application to the field, including $\mathrm{N}$ from manure, synthetic fertilizers, and crop residues. Indirect $\mathrm{N}_{2} \mathrm{O}$ emissions result from $\mathrm{N}$ that is removed 
Table 1. Production traits and feed requirements per cow, and yearly replacement rate of the dairy herd for the reference scenario and after increasing milk yield and longevity with 1 genetic $\mathrm{SD}^{1}$

\begin{tabular}{|c|c|c|c|c|c|c|c|c|}
\hline Item & \multicolumn{4}{|c|}{ Production traits } & \multicolumn{3}{|c|}{ Feed requirements ${ }^{2}$} & $\begin{array}{l}\text { Replacement } \\
\text { rate }(\%)\end{array}$ \\
\hline Increased milk yield & 9,445 & 4.32 & 3.51 & 2,150 & 46,961 & 583 & 6,137 & 27.0 \\
\hline Increased longevity & $8,795^{6}$ & 4.31 & 3.51 & 2,420 & 44,712 & 547 & 6,037 & 22.5 \\
\hline
\end{tabular}

${ }^{1}$ Genetic SD for milk yield is $687 \mathrm{~kg} / \mathrm{yr}$, and for longevity $270 \mathrm{~d}$ (CRV, 2012).

${ }^{2}$ The diet has to meet a minimum requirement for energy $\left(\mathrm{NE}_{\mathrm{L}}\right)$, a minimum requirement for true protein digested in the small intestine (DVE), and a minimum requirement for rumen-degradable protein balance (OEB, not included in the table, for all scenarios set to $0 \mathrm{~g} / \mathrm{d})$. In addition, a maximum for intake capacity is included ( $\mathrm{kg}$ of DM of the reference feed according to Jarrige, 1988).

${ }^{3}$ Longevity is defined as the actual age in days.

${ }^{4} \mathrm{DVE}=$ true protein digested in the small intestine according to Dutch standards (Tamminga et al., 1994).

${ }^{5}$ The reference scenario is based on an average Holstein Friesian dairy cow in 2013 (CRV, 2012).

${ }^{6}$ First lactation yield was the same as in the reference scenario.

from the farm via leaching of $\mathrm{NO}_{3}{ }^{-}$and volatilization of $\mathrm{NH}_{3}$ and $\mathrm{NO}_{\mathrm{x}}$ (IPCC, 2006). Emissions of $\mathrm{N}_{2} \mathrm{O}$ from crop residues were based on IPCC (2006). Other $\mathrm{N}_{2} \mathrm{O}$ emissions were based on national inventory reports and are described in more detail by Van Middelaar et al. (2013a).

Different GHG emissions were summed based on their equivalence factor in terms of $\mathrm{CO}_{2}$ equivalents $\left(\mathbf{C O}_{2} \mathbf{e}\right)$ (100-yr time horizon): 1 for $\mathrm{CO}_{2}, 25$ for $\mathrm{CH}_{4}$, and 298 for $\mathrm{N}_{2} \mathrm{O}$ (Forster et al., 2007). Emissions were calculated per tonne of FPCM (i.e., milk corrected to a fat percentage of $4.0 \%$ and a protein content of $3.3 \%$; Product Board Animal Feed, 2008). After summing emissions, they were allocated to the different outputs of the farm (i.e., milk and meat from culled calves and cows) based on the relative economic value of these outputs (i.e., economic allocation; Wageningen UR, 2008). Economic allocation is used most commonly in LCA studies of livestock products (De Vries and De Boer, 2010).

\section{Setup of the Analysis}

The LP model was used to determine the farm plan for a farm in the technical and institutional setting of 2020 and with a cow that has the same characteristics as an average Holstein Friesian cow in 2013. The farm area is 85 ha, which is the estimated size of an average Dutch dairy farm in 2020 (Rabobank, 2009). All manure produced on the farm needs to be applied on the farm (i.e., on grassland and maize land). Traits of the average cow, including milk yield, fat and protein content of the milk, and longevity, were based on the database of an international cattle improvement cooperative (CRV, 2012) and are included in Table 1. Table 1 also includes information on feed requirements. Based on the assumption that farmers become more efficient in the future, safety margins for true protein digested in the small intestine, as well as for rumen-degradable protein balance, were set to zero. In previous studies, safety margins for true protein digested in the small intestine were set at $100 \mathrm{~g} / \mathrm{cow}$ per day and $200 \mathrm{~g} /$ cow per day for rumen-degradable protein balance (Van Middelaar et al., 2013a). The maximum amount of fresh grass intake in summer was set to $12 \mathrm{~kg}$ of DM/cow per day, based on ad libitum grass intake of cows grazing during day times (Taweel et al., 2004; Abrahamse et al., 2009). Optimization of management variables based on maximizing labor income resulted in the reference scenario.

To determine the effect of a 1-unit change in milk yield and longevity, each trait was increased with 1 genetic SD while keeping the other traits constant. The genetic SD for milk yield of the Holstein Friesian breed in the Netherlands is $687 \mathrm{~kg} /$ cow per year ( $\mathrm{SD}$ applies to milk yield of a mature cow), and for longevity it is $270 \mathrm{~d}$ (CRV, 2012). Longevity was defined as the actual age in days. Using the model of Groen (1988), the effect of this change on average production, feed requirements, herd composition, and replacement rate was determined. Increasing milk yield increased feed requirements (Table 1). Increasing longevity changed herd composition (i.e., more cows in later lactations) and decreased replacement rate and number of young stock. Due to an increase in the number of cows in later lactations, milk yield of the average cow increased and fat content of the milk decreased. Increasing longevity, therefore, indirectly resulted in an increase in feed requirement of dairy cows due to an increased average weight and milk production (Table 1).

The new data on milk yield, feed requirements, and replacement rate for the 2 scenarios (i.e., increasing 
milk yield and increasing longevity) were incorporated in the model; subsequently, the effect on GHG emissions was determined by 1 of 2 methods. The first method maximized labor income and estimated the interrelated consequences for GHG emissions at chain level. The second method minimized GHG emissions per kilogram of milk and explored the potential of the traits (i.e., milk yield and longevity) to reduce these emissions. For the second method, 2 additional constraints were required. Labor income and total milk production at the farm level were required to be equal or higher than in the reference scenario. Labor income was restricted to estimate the potential of the traits to reduce GHG emissions without sacrificing income. Milk production was restricted to avoid milk that has to be produced somewhere else, which would indirectly mean an increase in GHG emissions from deforestation (i.e., more land required to produce the same amount of milk).

\section{Deriving Economic and GHG Values}

The economic value represents the change in labor income expressed per cow per year as a result of 1 genetic SD improvement on milk yield and longevity while keeping the other traits constant. Labor income was defined as gross returns minus variable and fixed costs (including depreciation and interest on fixed assets). Gross returns include revenues of selling of milk and meat (animals). Variable and fixed costs include feed costs, fertilizer costs, costs of building, and other variable and fixed costs. Change in labor income was calculated as labor income after change in genetic merit minus labor income before change in genetic merit. To calculate the economic value per trait, this change was divided by the number of dairy cows present before the change in genetic merit (Groen, 1989).

The GHG value represents the change in GHG emissions expressed per cow per year as a result of 1 genetic SD improvement on milk yield and longevity while keeping the other traits constant. Whereas deriving economic values is based on maximizing labor income at farm level, deriving GHG values is based on minimizing GHG per unit of product. Changes in GHG emissions were calculated as kilograms of $\mathrm{CO}_{2} \mathrm{e}$ per tonne of FPCM before a change in genetic merit minus kilograms of $\mathrm{CO}_{2} \mathrm{e}$ per tonne of FPCM after a change in genetic merit. To calculate the GHG values per trait, this change was multiplied with the FPCM production per cow per year before the change in genetic merit.

\section{Sensitivity Analysis}

Two main sources of uncertainty in assessments of GHG emissions of livestock products result from ac- counting for emissions from land use change (LUC) and handling the link between milk and meat production (i.e., co-product handling; Flysjö et al., 2012; Zehetmeier et al., 2012). In a sensitivity analysis, we explored the effect of including LUC emissions and using different methods for co-product handling using the results of the previous optimization.

Emissions from $\mathbf{L} \boldsymbol{U C}$. Land use change can have an important effect on GHG emissions and carbon sequestration. In the current study, 2 types of LUC are distinguished: on-farm LUC (i.e., conversion of grassland into maize land and vice versa) and off-farm LUC (i.e., deforestation caused by agricultural expansion).

Conversion of grassland into maize land results in nonrecurrent emissions due to a change in soil organic carbon stocks (Vellinga and Hoving, 2011; Van Middelaar et al., 2013a). Conversion of maize land into grassland, conversely, can contribute to carbon sequestration. Carbon sequestration was estimated to be $81 \mathrm{t}$ of $\mathrm{C} /$ ha for permanent grassland, and $41 \mathrm{t}$ of $\mathrm{C} / \mathrm{ha}$ for maize land (see Van Middelaar et al., 2013a). Conversion of grassland into maize land results in an emissions of $163 \mathrm{t}$ of $\mathrm{CO}_{2} \mathrm{e} /$ ha [see Van Middelaar et al. (2013a) for a detailed description of the calculation], whereas conversion of maize land into grassland reduces $\mathrm{CO}_{2}$ emissions by $147 \mathrm{t} /$ ha (40 t of extra $\mathrm{C}$ sequestration equals $147 \mathrm{t}$ of $\mathrm{CO}_{2}$ ).

Deforestation is another type of LUC that results in high amounts of GHG. Currently, forest is cleared on a large scale to provide land for crop cultivation and pasture. Because of the globalization of food and feed markets, it could be stated that every hectare of land that is used for commercial production is indirectly responsible for deforestation worldwide (Audsley et al., 2009). To determine the effect of LUC emissions on deforestation in our results, we used the method proposed by Audsley et al. (2009). They divided total GHG emissions from deforestation at the world scale for the year 2004 (based on Barker et al., 2007) by the total amount of land used for agricultural production, resulting in 1 emission factor of $1.43 \mathrm{t}$ of $\mathrm{CO}_{2} \mathrm{e} /$ ha of land. We applied this emission factor in our study and included on-farm land and land used to produce purchased feed products, including concentrates and maize silage (Table A2).

Methods for Handling of Co-Products. We allocated GHG emissions to milk and meat based on economic allocation. Another option to handle co-products is system expansion, implying that we account for changes in GHG emissions resulting from the production of additional co-products (i.e., meat from culled calves and cows). In that case, all emissions from processing calves and cows are attributed to milk, whereas emissions related to the production of meat that is 
replaced by these products, such as pork and chicken, are subtracted. By increasing milk yield and longevity, the ratio of milk over meat production changes, and methodological choices on how to handle co-products might affect results.

In the case of system expansion, emissions from processing of calves and cows and from the production of alternative products, such as pork and chicken, need to be calculated. For all meat products, we calculated emissions per kilogram of edible product and included processes up to the gate of the slaughterhouse. For culled dairy cows and young stock older than 12 mo, we assumed no further processing and included emissions related to transport and slaughtering only. Surplus calves were assumed to be sold to the white veal industry, which is most common in the Netherlands. Emissions related to processing of these calves were based on H. Mollenhorst (Wageningen UR, Wageningen, The Netherlands, personal communication) and include emissions from feeding, housing, transport, and slaughter. Assumptions on live weight, amount of edible products per animal, and emissions per kilogram of edible product from culled calves and cows are included in Table A3.

Meat from culled calves and cows was assumed to substitute either pork, chicken, or beef from suckler cows, in a ratio of 1:1, based on kilograms of edible product. Emissions from the production of pork, chicken, and beef were based on De Vries and De Boer (2010). De Vries and De Boer (2010) only included emissions up to the farm gate. Emissions related to transport and slaughtering, therefore, were based on the same method that was used for dairy cows. Total GHG emissions along the chain assumed was $7.3 \mathrm{~kg}$ of $\mathrm{CO}_{2} \mathrm{e} / \mathrm{kg}$ of edible pork, $5.6 \mathrm{~kg}$ of $\mathrm{CO}_{2} \mathrm{e} / \mathrm{kg}$ of edible chicken, and $23.4 \mathrm{~kg}$ of $\mathrm{CO}_{2} \mathrm{e} / \mathrm{kg}$ of edible beef. Calculations were made for all 3 alternatives. In the case of pork, for example, we multiplied the amount of edible products from culled calves and cows (i.e., based on the number of animal removed from the farm) with the emission factors presented in Table A3. Subsequently, we subtracted the same amount of edible products multiplied by the emission factor per kilogram of edible pork. The final result was added to the emissions related to dairy farming and divided by the total amount of FPCM to determine GHG emission per tonne of FPCM.

\section{RESULTS AND DISCUSSION}

\section{Maximizing Labor Income}

Diets and Farm Plan. Table 2 shows diets, farm plan, and farm outputs of the reference scenario and the scenarios in which milk yield and longevity were increased with 1 genetic SD. Results are based on maximizing labor income.

For the reference scenario the following results apply. In summer, the maximum amount of fresh grass is fed because grazing is the cheapest way of feeding. Subsequently, maize silage in combination with a small amount of medium protein concentrates is added to meet requirements for energy and rumen-degradable protein balance. In winter, the diet contains $2.7 \mathrm{~kg}$ of DM grass silage per cow per day, based on the amount of grass remained after grazing. Again, maize silage in combination with medium protein concentrates is added to meet requirements for energy and rumen-degradable protein balance. The reference scenario has 168 dairy cows, 59.5 ha of grassland, and 25.5 ha of maize land. The number of cows is based on the amount of manure that can be applied on the farm according to environmental legislation. In the reference scenario, application standards on the amount of $\mathrm{P}_{2} \mathrm{O}_{5}$ were restricting (Table 2). The area of grassland is exactly $70 \%$, which is the minimum requirement for farms to comply with the derogation regulation that allows the application of $250 \mathrm{~kg}$ of N/ha per year from animal manure, instead of $170 \mathrm{~kg}$ of $\mathrm{N} / \mathrm{ha}$ per year; total milk production is 1,543 t of FPCM/yr (i.e., 18.2 t of FPCM/ha). Current Dutch dairy farms on sandy soils produce on average about $13.4 \mathrm{t}$ of FPCM/ha (FADN, 2012). This means that our reference scenario is more intensive compared with current practice. This results from higher grass and maize yields per hectare (i.e., based on predicted increase in yield for 2020) and from application of precision feeding (i.e., ignoring safety margins for rumendegradable protein balance and true protein digested in the small intestine commonly applied in practice). Labor income in the reference scenario is $€ 115,050 / \mathrm{yr}$.

Increasing milk yield by 1 genetic SD changed the diets and farm plan of the reference scenario (Table 2). The number of cows increased and part of the maize land was changed into grassland. Diets were changed to meet the increasing requirements for energy and protein and because the area of grassland increased. This resulted from an increase in the number of cows and $\mathrm{P}_{2} \mathrm{O}_{5}$ application standards being restricting (more $\mathrm{P}_{2} \mathrm{O}_{5}$ from animal manure can be applied on grassland than on maize land). In the reference scenario, the costs of an increase in grassland at the expense of maize land were higher than the revenues of keeping more cows. After increasing milk yield, the revenues per cow increased and outweighed the costs of an increase in the area of grassland at the expense of maize land. After increasing milk yield, the number of cows and grassland increased until application standards for $\mathrm{N}$ from animal manure became restricting (Table 2). Total milk production at the farm level increased to 1,691 t of FPCM/ 
Table 2. Diets, farm plan, and farm outputs for the reference scenario and after increasing milk yield and longevity with 1 genetic SD, based on maximizing labor income

\begin{tabular}{|c|c|c|c|}
\hline Item & Reference & Milk yield & Longevity \\
\hline \multicolumn{4}{|l|}{ Diet ( $\mathrm{kg}$ of DM/cow per day) } \\
\hline \multicolumn{4}{|l|}{ Summer period } \\
\hline Grass silage, $225 \mathrm{~kg}$ of $\mathrm{N} / \mathrm{ha}$ & 12.0 & 12.0 & 12.0 \\
\hline Maize silage & 8.4 & 8.9 & 8.4 \\
\hline Concentrate, medium protein & 0.7 & 1.3 & 0.7 \\
\hline Diet restriction $^{1}$ & $\mathrm{E}, \mathrm{R}$ & $\mathrm{E}, \mathrm{R}$ & $\mathrm{E}, \mathrm{R}$ \\
\hline \multicolumn{4}{|l|}{ Winter period } \\
\hline Grass silage, $225 \mathrm{~kg}$ of $\mathrm{N} / \mathrm{ha}$ & 2.7 & 5.0 & 4.2 \\
\hline Maize silage & 8.0 & 8.9 & 8.4 \\
\hline Concentrate, medium protein & 6.5 & 4.6 & 5.0 \\
\hline Diet restriction ${ }^{1}$ & $\mathrm{E}, \mathrm{R}$ & $\mathrm{E}, \mathrm{R}$ & $\mathrm{E}, \mathrm{R}$ \\
\hline \multicolumn{4}{|l|}{ Farm plan } \\
\hline Dairy cows (n) & 168 & 171 & 182 \\
\hline Young stock ${ }^{2}(\mathrm{U})$ & 51 & 52 & 46 \\
\hline Grassland, $225 \mathrm{~kg}$ of N/ha (ha) & 59.5 & 67.9 & 67.4 \\
\hline Maize land (ha) & 25.5 & 17.1 & 17.6 \\
\hline \multicolumn{4}{|l|}{ Synthetic fertilizer } \\
\hline $\mathrm{kg}$ of N/ha & 107 & 113 & 112 \\
\hline $\mathrm{kg}$ of $\mathrm{P}_{2} \mathrm{O}_{5} / \mathrm{ha}$ & - & - & - \\
\hline Purchased maize silage ( $\mathrm{t}$ of $\mathrm{DM}$ ) & 207 & 396 & 381 \\
\hline Purchased concentrate ( $\mathrm{t}$ of $\mathrm{DM})$ & 247 & 207 & 213 \\
\hline Manure application restriction ${ }^{3}$ & $\mathrm{P}$ & $\mathrm{aN}, \mathrm{P}$ & $\mathrm{aN}, \mathrm{P}$ \\
\hline \multicolumn{4}{|l|}{ Farm output } \\
\hline Milk ( $\mathrm{t}$ of $\left.\mathrm{FPCM}^{4}\right)$ & 1,543 & 1,691 & 1,677 \\
\hline Dairy cows (n) & 45.3 & 46.0 & 40.9 \\
\hline Young stock, >12 mo (n) & 3.9 & 4.0 & 3.6 \\
\hline Young stock, <12 mo (n) & 2.1 & 2.1 & 1.9 \\
\hline Calves (n) & 116.8 & 118.6 & 135.7 \\
\hline Farm income $(€)$ & 115,050 & 135,477 & 128,765 \\
\hline
\end{tabular}

${ }^{1}$ The diet can be restricted by: $\mathrm{E}=$ energy requirements; $\mathrm{R}=$ rumen-degradable protein balance; $\mathrm{T}=$ true protein digested in the small intestine; $\mathrm{I}=$ intake capacity.

${ }^{2}$ One unit includes 1 animal $<12$ mo and 0.96 animal $>12$ mo.

${ }^{3}$ The intensity of the farm is restricted by the possibility to apply manure. Manure application can be restricted by $\mathrm{tN}=$ total mineral $\mathrm{N} ; \mathrm{aN}=\mathrm{N}$ from animal manure; $\mathrm{P}=\mathrm{P}_{2} \mathrm{O}_{5}$.

${ }^{4} \mathrm{FPCM}=$ fat- and protein-corrected milk.

yr, and labor income increased to $€ 135,477$. This is an increase of $€ 122 /$ cow per year.

Increasing longevity by 1 genetic SD reduced the replacement rate of the dairy herd (from $27.0 \%$ in the reference scenario to $22.5 \%$ after increasing longevity). Similar to milk yield, this resulted in a situation where maize land was changed into grassland to increase to amount of $\mathrm{P}_{2} \mathrm{O}_{5}$ that can be applied on the field, and hence the number of dairy cows. Because of the reduced replacement rate, less young stock was kept (Table 2), reducing manure production of the herd. As a result, the number of dairy cows increased to 182. Again, the application standard for $\mathrm{N}$ from animal manure limited a further increase of dairy cows. Total milk production at the farm level increased to 1,677 t of $\mathrm{FPCM} / \mathrm{yr}$, and labor income increased to $€ 128,765$; this is an increase of $€ 82 /$ cow per year.

GHG Emissions. Table 3 shows GHG emissions for the reference scenario and changes in emissions after increasing milk yield and longevity with 1 genetic SD. Results are based on maximizing labor income.
In the reference scenario, total GHG emissions per tonne of FPCM added up to $882 \mathrm{~kg}$ of $\mathrm{CO}_{2} \mathrm{e}$ without allocation, and $796 \mathrm{~kg}$ of $\mathrm{CO}_{2} \mathrm{e}$ based on economic allocation. The most important contributor was $\mathrm{CH}_{4}$ from enteric fermentation $(50 \%)$. Other important contributors were emissions from manure and from production of concentrates (both 13\%). Studies on current milk production systems find values around $1,000 \mathrm{~kg}$ of $\mathrm{CO}_{2} \mathrm{e} / \mathrm{t}$ of FPCM based on economic allocation (Flysjö et al., 2011; Zehetmeier et al., 2012; Van Middelaar et al., 2013a). Differences are explained by the higher productivity and efficiency representing the technical and institutional setting of 2020 in combination with precision feeding, compared with other studies that represent current production circumstances. These results imply that future dairy farms can reduce their environmental effect in terms of GHG emission per tonne of FPCM when aiming for an increase in efficiency.

Increasing milk yield by 1 genetic SD changed GHG emissions from various aspects (Table 3 ). Changes are expressed in kilograms of $\mathrm{CO}_{2} \mathrm{e}$ per tonne of FPCM 
Table 3. Greenhouse gas emissions for the reference scenario and the effect of increasing milk yield and longevity with 1 genetic SD (in $\mathrm{kg}$ of $\mathrm{CO}_{2}$ equivalent/t of fat- and protein-corrected milk) based on maximizing labor income

\begin{tabular}{|c|c|c|c|}
\hline Item & Reference & Milk yield & Longevity \\
\hline \multicolumn{4}{|l|}{ Animal emission } \\
\hline Enteric $\mathrm{CH}_{4}$ emission dairy cows & 372 & -5 & 3 \\
\hline Enteric $\mathrm{CH}_{4}^{4}$ emission young stock & 73 & -5 & -12 \\
\hline Manure & 118 & -5 & -6 \\
\hline \multicolumn{4}{|l|}{ On-farm feed production } \\
\hline Grassland & 67 & 6 & 6 \\
\hline Maize land & 37 & -14 & -13 \\
\hline \multicolumn{4}{|l|}{ Production of farm inputs } \\
\hline Maize silage & 24 & 18 & 17 \\
\hline Concentrate, dairy cows & 110 & -27 & -23 \\
\hline Concentrate, young stock & 8 & -1 & -1 \\
\hline Synthetic fertilizer & 51 & -2 & -2 \\
\hline Other inputs & 23 & -1 & 0 \\
\hline Total emissions & 882 & -36 & -32 \\
\hline Economic allocation & 796 & -27 & -23 \\
\hline
\end{tabular}

without allocation. Increasing milk yield per cow reduced emissions per tonne of FPCM by diluting emissions related to maintenance and young stock. In addition, emissions changed because of changes in diets and farm plan. Emissions from the production of purchased maize silage increased $\left(18 \mathrm{~kg}\right.$ of $\mathrm{CO}_{2} \mathrm{e} / \mathrm{t}$ of FCPM), because the amount of maize silage in the diets increased whereas the production of on-farm maize silage decreased. Given the decline in amount of concentrate required per tonne of FPCM, emissions from concentrate production decreased $(27 \mathrm{~kg}$ of $\mathrm{CO}_{2} \mathrm{e} / \mathrm{t}$ of $\mathrm{FPCM}$ ). Increasing milk yield by 1 genetic SD decreased total GHG emissions per tonne of FPCM by $36 \mathrm{~kg}$ of $\mathrm{CO}_{2} \mathrm{e}$ using no allocation, and by $27 \mathrm{~kg}$ of $\mathrm{CO}_{2} \mathrm{e}$ using economic allocation. Based on economic allocation, the GHG value of milk yield is $247 \mathrm{~kg}$ of $\mathrm{CO}_{2} \mathrm{e} /$ cow per year.

Increasing longevity by 1 genetic SD mainly affected emissions related to young stock and production of feed for dairy cows. Due to a lower replacement rate, emissions related to young stock (enteric $\mathrm{CH}_{4}$ and emissions from concentrate production) decreased by $13 \mathrm{~kg}$ of $\mathrm{CO}_{2} \mathrm{e} / \mathrm{t}$ of FPCM. Due to a change in the diets of dairy cows toward more roughage and less concentrates, emissions from production of grass and maize silage increased by $10 \mathrm{~kg}$ of $\mathrm{CO}_{2} \mathrm{e} / \mathrm{t}$ of $\mathrm{FPCM}$ (including on- and off-farm production), whereas emissions from production of concentrates decreased by 23 $\mathrm{kg}$ of $\mathrm{CO}_{2} \mathrm{e} / \mathrm{t}$ of FPCM (Table 3). Increasing longevity by 1 genetic SD decreased total GHG emissions per tonne of FPCM by $32 \mathrm{~kg}$ of $\mathrm{CO}_{2} \mathrm{e}$ using no allocation, and by $23 \mathrm{~kg}$ of $\mathrm{CO}_{2} \mathrm{e}$ using economic allocation. Based on economic allocation, the GHG value of longevity is $210 \mathrm{~kg}$ of $\mathrm{CO}_{2} \mathrm{e} / \mathrm{cow}$ per year, which is $15 \%$ lower than the GHG value of milk yield.

\section{Minimizing GHG Emissions}

Diets and Farm Plan. Table 4 shows diets, farm plan, and farm outputs of the reference scenario and the scenarios in which milk yield and longevity were increased by 1 genetic SD. Results for the scenarios with increased milk yield and longevity are based on minimizing GHG emissions per kilogram of milk. In all scenarios, labor income and total milk production had to equal or exceed the amounts of the reference scenario. The reference scenario and its results, therefore, are exactly the same as for the method based on maximizing labor income (Table 2).

Increasing milk yield by 1 genetic $\mathrm{SD}$ and, subsequently, minimizing GHG emissions per tonne of FPCM affected the diet and farm plan. Labor income and total milk production were not restricting, which means that the optimal solution within the feasible region was determined by other constraints. The level of $\mathrm{N}$ fertilization on grassland reduced from 225 to $200 \mathrm{~kg}$ of $\mathrm{N} / \mathrm{ha}$ per year. A reduction in $\mathrm{N}$ fertilization on grassland reduced emissions from cultivation per kilogram of DM grass and grass silage, whereas enteric $\mathrm{CH}_{4}$ emissions increased (Table A3). Within the limits of environmental legislations on the application of manure, a fertilization level of $200 \mathrm{~kg}$ of $\mathrm{N} /$ ha per year resulted in the lowest GHG emissions per tonne of FPCM. The amount of concentrates in the diets was minimized. In summer, a decrease in kilograms of DM grass per cow per day allowed for an increase in kilograms of DM maize silage per cow per day, and a maximum roughage uptake within the limiting intake capacity. Also, in winter, the maximum amount of roughage was fed. In both diets, high-protein concentrates were added to fulfill requirements 
Table 4. Diets, farm plan, and farm outputs for the reference scenario and after increasing milk yield and longevity with 1 genetic SD, based on minimizing greenhouse gas emissions

\begin{tabular}{|c|c|c|c|}
\hline Item & Reference & Milk yield & Longevity \\
\hline \multicolumn{4}{|l|}{ Diet ( $\mathrm{kg}$ of $\mathrm{DM} /$ cow per day) } \\
\hline \multicolumn{4}{|l|}{ Summer period } \\
\hline Grass, $200 \mathrm{~kg}$ of $\mathrm{N} / \mathrm{ha}$ & - & 11.7 & 12.0 \\
\hline Grass, $225 \mathrm{~kg}$ of $\mathrm{N} / \mathrm{ha}$ & 12.0 & - & - \\
\hline Maize silage & 8.4 & 9.3 & 8.4 \\
\hline Concentrate, medium protein & 0.7 & - & - \\
\hline Concentrate, high protein & - & 1.3 & 0.8 \\
\hline Diet restriction $^{1}$ & E,R & E,R,I & $\mathrm{E}, \mathrm{R}$ \\
\hline \multicolumn{4}{|l|}{ Winter period } \\
\hline Grass silage, $200 \mathrm{~kg}$ of $\mathrm{N} / \mathrm{ha}$ & - & 4.5 & 5.3 \\
\hline Grass silage, $225 \mathrm{~kg}$ of N/ha & 2.7 & - & - \\
\hline Maize silage & 8.0 & 11.2 & 10.4 \\
\hline Concentrate, medium protein & 6.5 & - & - \\
\hline Concentrate, high protein & - & 2.9 & 2.3 \\
\hline Diet restriction $^{1}$ & $\mathrm{E}, \mathrm{R}$ & $\mathrm{E}, \mathrm{R}, \mathrm{I}$ & $\mathrm{E}, \mathrm{R}, \mathrm{I}$ \\
\hline \multicolumn{4}{|l|}{ Farm plan } \\
\hline Dairy cows (n) & 168 & 157 & 178 \\
\hline Young stock ${ }^{2}(\mathrm{U})$ & 51 & 48 & 45 \\
\hline Grassland, $200 \mathrm{~kg}$ of N/ha (ha) & - & 62.4 & 72.5 \\
\hline Grassland, $225 \mathrm{~kg}$ of $\mathrm{N} / \mathrm{ha}$ (ha) & 59.5 & - & - \\
\hline Maize land (ha) & 25.5 & 22.6 & 12.5 \\
\hline \multicolumn{4}{|l|}{ Synthetic fertilizer } \\
\hline $\mathrm{kg}$ of $\mathrm{N} / \mathrm{ha}$ & 107 & 92 & 95 \\
\hline $\mathrm{kg} \mathrm{P}_{2} \mathrm{O}_{5} / \mathrm{ha}$ & - & - & - \\
\hline Purchased maize silage ( $\mathrm{t}$ of $\mathrm{DM}$ ) & 207 & 338 & 512 \\
\hline Purchased concentrate ( $\mathrm{t}$ of $\mathrm{DM})$ & 247 & 141 & 117 \\
\hline Manure application restriction $^{3}$ & $\mathrm{P}$ & $\mathrm{P}$ & $\mathrm{P}$ \\
\hline \multicolumn{4}{|l|}{ Farm output } \\
\hline Milk ( $\mathrm{t}$ of fat- and protein-corrected milk) & 1,543 & 1,558 & 1,640 \\
\hline Dairy cows (n) & 45.3 & 42.4 & 40.0 \\
\hline Young stock, >12 mo (n) & 3.9 & 3.7 & 3.5 \\
\hline Young stock, <12 mo (n) & 2.1 & 1.9 & 1.8 \\
\hline Calves (n) & 116.8 & 109.3 & 132.7 \\
\hline Farm income $(€)$ & 115,050 & 127,301 & 120,428 \\
\hline
\end{tabular}

${ }^{1}$ The diet can be restricted by: $\mathrm{E}=$ energy requirements; $\mathrm{R}=$ rumen-degradable protein balance; $\mathrm{T}=$ true protein digested in the small intestine; I = intake capacity.

${ }^{2}$ One unit includes 1 animal $<12$ mo and 0.96 animal $>12$ mo.

${ }^{3}$ The intensity of the farm is restricted by the possibility to apply manure. Manure application can be restricted by: $\mathrm{P}=\mathrm{P}_{2} \mathrm{O}_{5}$.

for rumen-degradable protein balance. Although concentrates result in a lower enteric $\mathrm{CH}_{4}$ emission than grass and grass silage, emissions during production are much higher (Table A2). The number of cows was restricted by $\mathrm{P}$ application standards and the area of grassland (because application standards are higher for grassland than for maize land). The area of grassland was determined by the amount of grass and grass silage in the diet, and hence by the maximum intake capacity of the cow. With total milk production as a minimum constraint, the number of cows increased as long as the increase in grass and grass silage was fully consumed and $\mathrm{P}$ application standards were not restricting. After increasing milk yield, this balance was reached at 157 cows, which is lower than the number of cows in the reference scenario. Total milk production increased from 1,543 to 1,558 t of FPCM/yr, and labor income from $€ 115,050$ to $€ 127,301 / y r$; this is an increase of $€ 73 /$ cow per year.

Increasing longevity resulted in a similar strategy as increasing milk yield. Nitrogen fertilization on grassland reduced to $200 \mathrm{~kg}$ of $\mathrm{N} / \mathrm{ha}$ per year and the amount of concentrates was minimized. The number of cows increased to 178; a further increase was restricted by $\mathrm{P}$ application standards in combination with limits to the amount of grass and grass silage in the diets. Total milk production increased to $1,640 \mathrm{t}$ of $\mathrm{FPCM} / \mathrm{yr}$, and labor income to $€ 120,428 / y r$; this is an increase of $€ 32 /$ cow per year.

GHG Emissions. Table 5 shows GHG emissions of the reference scenario and changes in emissions after increasing milk yield and longevity with 1 genetic SD. Results are based on minimizing GHG emissions per kilogram of milk. For the reference scenario, results are 
Table 5. Greenhouse gas emissions for the reference scenario and the effect of increasing milk yield and longevity with 1 genetic SD (in $\mathrm{kg}$ of $\mathrm{CO}_{2}$ equivalent/t of fat- and protein-corrected milk) based on minimizing greenhouse gas emissions

\begin{tabular}{lccc}
\hline Item & Reference & Milk yield & Longevity \\
\hline Animal emission & & & \\
Enteric $\mathrm{CH}_{4}$ emission, dairy cows & 372 & -2 & 11 \\
Enteric $\mathrm{CH}_{4}$ emission, young stock & 73 & -5 & -12 \\
Manure & 118 & -5 & -5 \\
On-farm feed production & & -1 & 8 \\
Grassland & 67 & -5 & -20 \\
$\quad$ Maize land & 37 & 15 & 32 \\
Production of farm inputs & 24 & -48 & -62 \\
Maize silage & 110 & -1 & -1 \\
Concentrate, dairy cows & 8 & -8 & -8 \\
Concentrate, young stock & 51 & 0 & 0 \\
Synthetic fertilizer & 23 & -60 & -59 \\
Other inputs & 882 & -49 & -48 \\
Total emissions & 796 & & \\
Economic allocation & & & \\
\hline
\end{tabular}

exactly the same as for the method based on maximizing labor income (Table 3).

After increasing milk yield per cow, $\mathrm{N}$ fertilization on grassland was decreased and the diets of the dairy cows were changed. Per tonne of FPCM, emissions related to on-farm feed production, enteric fermentation, and production of various farm inputs decreased. Most important was the reduction in emissions from concentrates production (48 kg of $\mathrm{CO}_{2} \mathrm{e} / \mathrm{t}$ of $\mathrm{FPCM}$ without allocation). Emissions from the production of purchased maize silage were the only emissions that increased ( $15 \mathrm{~kg}$ of $\mathrm{CO}_{2} \mathrm{e} / \mathrm{t}$ of $\mathrm{FPCM}$ ). Overall, emissions per tonne of FPCM decreased by $60 \mathrm{~kg}$ of $\mathrm{CO}_{2} \mathrm{e}$ using no allocation, and by $49 \mathrm{~kg}$ of $\mathrm{CO}_{2} \mathrm{e}$ using economic allocation. Based on economic allocation, the GHG value of milk yield is $453 \mathrm{~kg}$ of $\mathrm{CO}_{2} \mathrm{e} / \mathrm{cow}$ per year.

After increasing longevity, the number of young stock decreased, $\mathrm{N}$ fertilization on grassland decreased, and the diets of dairy cows changed. Per tonne of FPCM, emissions related to young stock, on-farm feed production, and production of synthetic fertilizer decreased; most significant was the reduction in emissions from concentrate production. Emissions from production of purchased maize silage and enteric fermentation of dairy cows increased. Overall, emissions per tonne of FPCM decreased by $59 \mathrm{~kg}$ of $\mathrm{CO}_{2} \mathrm{e}$ using no allocation, and by $48 \mathrm{~kg}$ of $\mathrm{CO}_{2} \mathrm{e}$ using economic allocation. Based on economic allocation, the GHG value of longevity is $441 \mathrm{~kg}$ of $\mathrm{CO}_{2} \mathrm{e} /$ cow per year, which is $3 \%$ lower than the GHG value of milk yield.

\section{Sensitivity Analysis}

Emissions from $\boldsymbol{L} \boldsymbol{U}$ C. It is important to realize that changing genetic traits does not only affect annual emissions, but can also affect nonrecurrent emissions related to on-farm LUC. After increasing milk yield and longevity, maize land was changed into grassland contributing to $\mathrm{CO}_{2}$ sequestration. Using method 1, this change in land use resulted in sequestration of 667 $\mathrm{kg}$ of $\mathrm{CO}_{2} \mathrm{e} / \mathrm{t}$ of FPCM per unit change of milk yield, and $636 \mathrm{~kg}$ of $\mathrm{CO}_{2} \mathrm{e} / \mathrm{t}$ of $\mathrm{FPCM}$ per unit change of longevity. Using method 2, sequestration was $252 \mathrm{~kg}$ of $\mathrm{CO}_{2} \mathrm{e} / \mathrm{t}$ of FPCM for milk yield and $1,062 \mathrm{~kg}$ of $\mathrm{CO}_{2} \mathrm{e} / \mathrm{t}$ of FPCM for longevity. Results show that both traits result in $\mathrm{CO}_{2}$ sequestration due to on-farm LUC. Using method 1, the importance of milk yield relative to longevity increases, whereas for method 2 the importance of longevity increases. Opposite the annual emissions used to calculate GHG values, emissions from on-farm LUC are nonrecurrent and therefore cannot be included in the GHG value of traits.

Emissions from deforestation were calculated for 2004 (Barker et al., 2007; Audsley et al., 2009). Under the assumption that the rate of deforestation in 2004 can be used as an indicator for other years, emissions from deforestation were treated as recurrent emissions and included in the GHG values. Using method 1, including emissions from deforestation increased the GHG value of milk yield from 247 to $260 \mathrm{~kg}$ of $\mathrm{CO}_{2} \mathrm{e} /$ cow per year and of longevity from 210 to $219 \mathrm{~kg}$ of $\mathrm{CO}_{2} \mathrm{e} / \mathrm{cow}$ per year. This increase in GHG values resulted from a decrease in land use per tonne of FPCM. Using method 2, the GHG value of milk yield decreased from 453 to 435 $\mathrm{kg}$ of $\mathrm{CO}_{2} \mathrm{e} /$ cow per year and of longevity from 441 to $406 \mathrm{~kg}$ of $\mathrm{CO}_{2} \mathrm{e} / \mathrm{cow}$ per year. Including emissions from deforestation did not affect the relative importance of the traits and the absolute change in GHG values was limited. When the pressure on land use and the importance of deforestation increases, it can become relevant to include emissions from deforestation in GHG values and in the optimization procedure. Because of high 
Table 6. Greenhouse gas (GHG) values of milk yield and longevity ( $\mathrm{kg}$ of $\mathrm{CO}_{2}$ equivalent/cow per year) using different methods for handling co-products, based on maximizing labor income and minimizing GHG emissions

\begin{tabular}{lccccc}
\hline & \multicolumn{2}{c}{ Maximizing labor income } & & \multicolumn{2}{c}{ Minimizing GHG emissions } \\
\cline { 2 - 3 } \cline { 5 - 6 } Item & Milk yield & Longevity & & Milk yield & Longevity \\
\hline No allocation or system expansion & 326 & 291 & & 552 & 544 \\
Economic allocation & 247 & 210 & & 453 & 441 \\
System expansion & & & & 529 & 439 \\
Pork & 303 & 186 & & 547 & 453 \\
Chicken & 133 & 501 & & 359 & 302 \\
Beef & 133 & 50 & & \\
\hline
\end{tabular}

uncertainty and variation in calculating emissions from deforestation, and because they differ in nature from annual emissions at farm-level, GHG values should be presented with and without emissions from deforestation (Van Middelaar et al., 2013b; Flysjö et al., 2012).

Methods for Handling of Co-Products. Table 6 shows the GHG values of milk yield and longevity using different methods for handling of co-products. Results show that methodological choices affect GHG values.

The GHG values of milk yield and longevity change when using system expansion instead of economic allocation and vary for different alternative products (Table 6). The absolute change in GHG values was the same for method 1 and 2. With system expansion, the difference in GHG values between milk yield and longevity are larger than with economic allocation. When longevity increases, fewer cows but more calves are culled. Because calves have a higher emission factor per kilogram of edible product than cows, increasing longevity increased emissions related to processing of culled animals, and hence resulted in a lower GHG value than an increase in milk yield.

Of the 3 alternative products, beef resulted in the lowest GHG values. Producing beef results in high emissions. Under the assumption that meat from culled calves and cows replaces beef from suckler cows, these emissions are subtracted from the GHG emissions of milk. An increase in milk yield or longevity means that, per kilogram of FPCM, less meat is produced that can substitute beef, and hence fewer emissions are subtracted per kilogram of FPCM. When fewer emissions are subtracted, total reduction per kilogram of FPCM is lower, and therefore so is the GHG value. Overall, these results indicate that increasing milk yield results in a higher GHG value than longevity when co-products are included in the analyses.

\section{General Discussion}

Using method 1, increasing milk yield with $687 \mathrm{~kg} /$ cow per year reduced GHG emissions by $4.1 \%$ to $6.8 \%$ (no allocation or system expansion). Bell et al. (2011) found a reduction of 9.5 to $13.2 \%$ per genetic SD improvement of 1,241 kg of ECM/cow per year; those authors, however, increased milk yield while maintaining the same feed intake, which makes direct comparison difficult. For longevity, we found a reduction in GHG emissions of 3.6 to $6.7 \%$ when increasing the average number of lactations from 3.25 to 3.90 (no allocation or system expansion). Wall et al. (2010) found a reduction of $4.3 \%$ when increasing longevity from 3.0 to 3.5 lactations, but only included $\mathrm{CH}_{4}$ and $\mathrm{N}_{2} \mathrm{O}$ emissions at farm level. Both Wall et al. (2010) and Bell et al. (2011) did not optimize farm management with changing levels of genetic traits, which can lead to over- or underestimation; they also used different methods to calculate emissions. To calculate enteric $\mathrm{CH}_{4}$ emissions, for example, we used feed-specific emission factors derived from mechanistic modeling techniques. This method is found to be more precise than the IPCC Tier 1 and 2 methods that were used by Wall et al. (2010) and Bell et al. (2011) (Kebreab et al., 2008; Alemu et al., 2011). Harmonization of methods to calculate GHG values is important when breeding organizations want to include environmental performance into their breeding goal.

Based on the results presented in the current study, milk yield is more important than longevity when both economics and reducing GHG emission are relevant (method 1: the economic value of milk yield is $49 \%$ higher than the value of longevity and the GHG value is $18 \%$ higher). If only reducing GHG emissions is relevant, milk yield and longevity are approximately equally important (method 2: the GHG value of milk yield is only $3 \%$ higher than the value of longevity). In that case, however, milk yield still has a higher economic value than longevity ( $€ 73 /$ cow per year compared with €32/cow per year). This indicates that, in a situation where labor income becomes restricting, milk yield could result in a higher GHG value than longevity because more money is available to implement improvement options.

Results were based on a situation without output limitations, which allows for a change in the number of 
cows. In addition, management factors, such as on-farm roughage production and purchases of feed, changed with a change in trait. As a result, GHG values not only represent the direct effect of a change in traits, but also the indirect effect due to changes in the number of cows and management factors. Because these factors are variable and can be influenced by the traits of the cow, including both direct and indirect effects, a change in traits was assumed to be most accurate for estimating GHG values.

Differences in diets and farm plan between method 1 and 2 show that dairy farmers are likely to change their management when standards to reduce GHG emissions are introduced. Compared with method 1, method 2 resulted in a reduction in $\mathrm{N}$ fertilization on grassland, and a reduction in the amount of concentrates. Results of both methods are influenced by the reference scenario, including farm size and environmental policies. In addition, production characteristics of the average cow in the reference scenario might have influenced results. This means that changing the constraints of the model or aspects of the reference scenario might change the results (Berentsen and Tiessink, 2003). Before using GHG values to define the breeding goal, the effect of such changes should be considered. Furthermore, a wider sensitivity analysis regarding prices and emission factors is required to verify the relative value of traits.

Methods used to calculate relative GHG values of genetic traits included not only emissions at farm level, but also emissions from the production of farm inputs (e.g., purchased feed). Although the dairy sector is not responsible for reducing emissions from industrial processes related to the production of farm-inputs, it is important to consider these off-farm emissions in the analysis. Excluding these emissions might yield strategies that reduce emissions at farm level, but increase emissions during production of farm-inputs (i.e., pollution swapping). By purchasing feed ingredients with a low environmental effect, dairy farmers can contribute to reduced emissions. In addition, this approach is consistent with accounting for costs of farm inputs in the calculation of economic values.

To illustrate the 2 methods presented in the current study, we only considered the effect of an increase in milk yield and longevity. Correlations between traits were not considered because we assumed that these traits will be included in the breeding goal. When calculating GHG values of longevity, we did not account for the potential loss in genetic gain through replacement heifers being genetically superior to older cows. Including this potential loss would decrease GHG values of longevity.

The need to include GHG values into breeding goals is currently limited, but might increase because of the increasing concerns about GHG emissions. Relative GHG values can be used in a similar way as economic values (i.e., to determine which traits are most important when aiming for a certain goal, in this case minimizing GHG emissions).

Results show that $\mathrm{N}_{2} \mathrm{O}$ emissions related to $\mathrm{N}$ fertilization of grassland are negatively correlated with $\mathrm{CH}_{4}$ emissions related to enteric fermentation of grass and grass silage from grassland. Thus, reducing $\mathrm{N}$ fertilization on grassland reduces $\mathrm{N}_{2} \mathrm{O}$ emissions, but increases enteric $\mathrm{CH}_{4}$ emissions. Hence, the net effect on GHG emissions per tonne of milk is minimal, and reducing $\mathrm{N}$ fertilization on grassland below $200 \mathrm{~kg}$ of $\mathrm{N} / \mathrm{ha}$ in a situation similar to our study does not pay off.

\section{CONCLUSIONS}

Both methods presented in the current study provide insight into the GHG value of genetic traits, but give different information. Which method to use depends on the objective of the dairy industry and the standards they have to meet. Method 1 shows the GHG value of traits in situations where maximizing labor income is the main objective, which relates to current practice. Method 2 shows the full potential of traits to reduce GHG emissions given the boundaries that were set for income and milk production, and relates to a situation where lowering emissions becomes more important than increasing income. Calculating GHG values of milk yield and longevity shows that the full potential of both traits to reduce GHG is about twice as high as the reduction based on maximizing labor income. In addition, milk yield has a higher GHG value than longevity, especially when the focus is on maximizing labor income. Including emissions from LUC and using different methods for handling co-products generally changed results further in favor of milk yield. Results can be used by breeding organizations that want to include GHG values in their breeding goal. To verify GHG values, the effect of prices and emissions factors should be considered, as well as the potential effect of variation between farm types.

\section{ACKNOWLEDGMENTS}

We thank CRV BV (Arnhem, the Netherlands), Agrifirm Group (Apeldoorn, the Netherlands), and the Ministry of Infrastructure and the Environment (Den Haag, the Netherlands) for financially supporting this research.

\section{REFERENCES}

Abrahamse, P. A., S. Tamminga, and J. Dijkstra. 2009. Effect of daily movement of dairy cattle to fresh grass in morning or afternoon 
on intake, grazing behaviour, rumen fermentation and milk production. J. Agric. Sci. 147:721-730. http://dx.doi.org/10.1017/ S0021859609990153.

Alemu, A. W., J. Dijkstra, A. Bannink, J. France, and E. Kebreab. 2011. Rumen stoichiometric models and their contribution and challenges in predicting enteric methane production. Anim. Feed Sci. Technol. 166-167:761-778.

Audsley, E., M. Brander, J. Chatterton, D. Murphy-Bokern, C. Webster, and A. Williams. 2009. How low can we go? An assessment of greenhouse gas emissions from the UK food system and the scope to reduce them by 2050. Report for the WWF and Food Climate Research Network. Cranfield University, United Kingdom.

Bannink, A., J. Kogut, J. Dijkstra, J. France, E. Kebreab, A. M. Van Vuuren, and S. Tamminga. 2006. Estimation of the stoichiometry of volatile fatty acid production in the rumen of lactating cows. J. Theor. Biol. 238:36-51.

Bannink, A., M. W. van Schijndel, and J. Dijkstra. 2011. A model of enteric fermentation in dairy cows to estimate methane emission for the Dutch National Inventory Report using the IPCC Tier 3 approach. Anim. Feed Sci. Technol. 166-167:603-618.

Barker, T., I. Bashmakov, L. Bernstein, J. E. Bogner, P. R. Bosch, R. Dave, O. R. Davidson, B. S. Fisher, S. Gupta, K. Halsnæs, G. J. Heij, S. Kahn Ribeiro, S. Kobayashi, M. D. Levine, D. L. Martino, O. Masera, B. Metz, L. A. Meyer, G. J. Nabuurs, A. Najam, N. Nakicenovic, H. H. Rogner, J. Roy, J. Sathaye, R. Schock, P. Shukla, R. E. H. Sims, P. Smith, D. A. Tirpak, D. Urge-Vorsatz, and D. Zhou. 2007. Technical Summary. In Climate Change 2007: Mitigation. Contribution of Working Group III to the Fourth Assessment Report of the Intergovernmental Panel on Climate Change. B. Metz, O. R. Davidson, P. R. Bosch, R. Dave, L. A. Meyer, ed. Cambridge University Press, Cambridge, UK, and New York, NY.

Bauman, H., and A. M. Tillman. 2004. The Hitchhiker's Guide to LCA. Chalmers University of Technology, Goteborg, Sweden.

Bell, M. J., E. Wall, G. Russell, C. Morgan, and G. Simm. 2010. Effect of breeding for milk yield, diet and management on enteric methane emissions from dairy cows. Anim. Prod. 50:817-826.

Bell, M. J., E. Wall, G. Russell, G. Simm, and A. W. Stott. 2011. The effect of improving cow productivity, fertility, and longevity on the global warming potential of dairy systems. J. Dairy Sci. 94:3662-3678.

Berentsen, P. B. M., and G. W. J. Giesen. 1995. An environmentaleconomic model at farm level to analyse institutional and technical change in dairy farming. Agric. Syst. 49:153-175.

Berentsen, P. B. M., G. W. J. Giesen, and J. A. Renkema. 1996. Scenarios of technical and institutional change in Dutch dairy farming. Neth. J. Agric. Sci. 44:193-208.

Berentsen, P. B. M., and M. Tiessink. 2003. Potential effects of accumulating environmental policies on Dutch dairy farms. J. Dairy Sci. 86:1019-1028.

Buddle, B. M., M. Denis, G. T. Attwood, E. Altermann, P. H. Janssen, R. S. Ronimus, C. S. Pinares-Patiño, S. Muetzel, and D. Neil Wedlock. 2011. Strategies to reduce methane emissions from farmed ruminants grazing on pasture. Vet. J. 188:11-17.

CRV. 2012. International Dutch cattle improvement co-operative. Handboek CRV Hoofdstuk E-20 p. 2. Accessed Dec. 11, 2012. www.crv4all.nl/downloads/e-hoofdstukken/e20.pdf.

De Mol, R. M., and M. A. Hilhorst. 2003. Emissions of methane, nitrous oxide and ammonia from production, storage and transport of manure. Report 2003-03. Institute of Agricultural and Environmental Engineering, Wageningen UR, the Netherlands. In Dutch, with summary in English.

De Vries, M., and I. J. M. De Boer. 2010. Comparing environmental impacts for livestock products: A review of life cycle assessments. Livest. Sci. 128:1-11.

Dijkstra, J., H. D. S. C. Neal, D. E. Beever, and J. France. 1992. Simulation of nutrient digestion, absorption and outflow in the rumen: Model description. J. Nutr. 122:2239-2256.

Ecoinvent. 2007. Ecoinvent Data v2.0 Final Reports Ecoinvent 2007. CD-ROM. Database in the LCA software SimaPro 7.3; PRé Consultants bv, 2007. R. Frischknecht, and N. Jungbluth, ed. Swiss Centre for Life Cycle Inventories, Dubendorf, Switzerland.
FADN (Farm Accountancy Data Network). 2012. Farm Accountancy Data Network. Accessed Apr. 4, 2012. http://www.wageningenur. nl/en/Expertise-Services/Research-Institutes/lei/Statistics / Binternet-1.htm.

Finnish Environmental Institute. 2002. The Finnish Environment: Finnish expert report on best available techniques in slaughterhouses and installations for the disposal or recycling of animal carcasses and animal waste. Report 539. Finnish Environmental Institute, Helsinki, Finland. Accessed Mar. 22, 2013. www. ymparisto.fi/download/noname/\%7B8D6E68E3-826F-4AE3A49D-BC873D8480D6\%7D/57242.

Flysjö, A., C. Cederberg, M. Henriksson, and S. Ledgard. 2012. The interaction between milk and beef production and emissions from land use change-Critical considerations in life cycle assessment and carbon footprint studies of milk. J. Clean. Prod. 28:134-142.

Flysjö, A., M. Henriksson, C. Cederberg, S. Ledgard, and J. E. Englund. 2011. The impact of various parameters on the carbon footprint of milk production in New Zealand and Sweden. Agric. Syst. 104:459-469

Forster, P., V. Ramaswamy, P. Artaxo, T. Berntsen, R. Betts, D. W Fahey, J. Haywood, J. Lean, D. C. Lowe, G. Myhre, J. Nganga, R. Prinn, G. Raga, M. Schulz, and R. Van Dorland. 2007. Changes in Atmospheric Constituents and in Radiative Forcing. Climate Change 2007: The Physical Science Basis. Contribution of Working Group I to the Fourth Assessment Report of the Intergovernmental Panel on Climate Change. S. Solomon, D. Qin, M. Manning, Z. Chen, M. Marquis, K. B. Averyt, M. Tignor and H. L. Miller, ed. Cambridge University Press, Cambridge, UK, and New York, NY

Garnsworthy, P. C. 2004. The environmental impact of fertility in dairy cows: A modelling approach to predict methane and ammonia emissions. Anim. Feed Sci. Technol. 112:211-223.

Groen, A. F. 1988. Derivation of economic values in cattle breeding: A model at farm level. Agric. Syst. 27:195-213.

Groen, A. F. 1989. Cattle breeding goals and production circumstances. PhD Thesis, Department of Farm Management and Department of Animal Breeding, Wageningen Agricultural University, Wageningen, the Netherlands.

Groen, A. F., T. Steine, J. J. Colleau, J. Pedersen, J. Pribyl, and N. Reinsch. 1997. Economic values in dairy cattle breeding, with special reference to functional traits. Report of an EAAP-working group. Livest. Prod. Sci. 49:1-21.

Haas, Y., J. J. Windig, M. P. L. Calus, J. Dijkstra, M. de Haan, A. Bannink, and R. F. Veerkamp. 2011. Genetic parameters for predicted methane production and potential for reducing enteric emissions through genomic selection. J. Dairy Sci. 94:6122-6134.

Hörtenhuber, S., T. Lindenthal, B. Amon, T. Markut, L. Kirner, and W. Zollitsch. 2010. Greenhouse gas emissions from selected Austrian dairy production systems-Model calculations considering the effects of land use change. Renew. Agric. Food Syst. 25:316-329.

IPCC (Intergovernmental Panel on Climate Change). 2006. Guidelines for National Greenhouse Gas Inventories. Volume 4: Agriculture, Forestry and Other Land Use. Prepared by the National Greenhouse Gas Inventories Program. H. S. Eggleston, L. Buendia, K. Miwa, T. Ngara, and K. Tanabe, ed. IGES, Kanagawa, Japan.

IPCC (Intergovernmental Panel on Climate Change). 2007. Climate change 2007: Synthesis report. Contribution of Working Groups I, II and III to the Fourth Assessment Report of the Intergovernmental Panel on Climate Change. R. K. Pachauri and A. Reisinger, ed. IPCC, Geneva, Switzerland.

Jarrige, R. 1988. Alimentation des bovins, ovins et caprins. Institut National de la Recherche Agronomique, Paris, France. (In French).

Kebreab, E., K. A. Johnson, S. L. Archibeque, D. Pape, and T. Wirth. 2008. Model for estimating enteric methane emissions from United States dairy and feedlot cattle. J. Anim. Sci. 86:2738-2748.

Koenen, E. P. C., P. B. M. Berentsen, and A. F. Groen. 2000. Economic values of live weight and feed-intake capacity of dairy cattle under Dutch production circumstances. Livest. Prod. Sci. 66:235-250.

Mills, J. A. N., J. Dijkstra, A. Bannink, S. B. Cammell, E. Kebreab, and J. France. 2001. A mechanistic model of whole-tract digestion 
and methanogenesis in the lactating dairy cow: Model development, evaluation, and application. J. Anim. Sci. 79:1584-1597.

Product Board Animal Feed. 2008. Tabellenboek Veevoeding 2008. Productschap Diervoeder, CVB, Den Haag, the Netherlands.

Rabobank. 2009. Rapport Anders melken. De toekomst van de Nederlandse melkveehouderij. Report on prospects of the Dutch dairy sector for the year 2020. (in Dutch). Food and Agric. Team Rabobank, Centraal Twente, Hengelo, the Netherlands.

Rebitzer, G., T. Ekvall, R. Frischknecht, D. Hunkeler, G. Norris, T. Rydberg, W. P. Schmidt, S. Suh, B. P. Weidema, and D. W. Pennington. 2004. Life cycle assessment part 1: Framework, goal and scope definition, inventory analysis, and applications. Environ. Int. 30:701-720.

Remmelink, G., K. Blanken, J. van Middelkoop, W. Ouweltjes, and H. Wemmelhove. 2012. Handboek melkveehouderij. Wageningen UR Livestock Research. (in Dutch). Accessed Feb. 14, 2013. www. handboekmelkveehouderij.nl.

Rijk, H., M. K. van Ittersum, and J. Withagen. 2013. Genetic progress in Dutch crop yields. Field Crops Res. 149:262-268.

Sebek, L.B.J., and E.H.M. Temme. 2009. Human protein requirements and protein intake and the conversion of vegetable protein into animal protein. Report 232. Animal Science Group, Wageningen UR, Wageningen, the Netheralnds. (In Dutch).

Tamminga, S., W. M. Van Straalen, A. P. J. Subnel, R. G. M. Meijer, A. Steg, C. J. G. Wever, and M. C. Blok. 1994. The Dutch protein evaluation system: The DVE/OEB system. Livest. Prod. Sci. 40:139-155.

Taweel, H. Z., B. M. Tas, J. Dijkstra, and S. Tamminga. 2004. Intake regulation and grazing behavior of dairy cows under continuous stocking. J. Dairy Sci. 87:3417-3427.

Thomassen, M. A., K. J. Van Calker, M. C. J. Smits, G. L. Iepema, and I. J. M. De Boer. 2008. Life cycle assessment of conventional and organic milk production in the Netherlands. Agric. Syst. 96:95-107.

Van Middelaar, C. E., P. B. M. Berentsen, J. Dijkstra, and I. J. M. de Boer. 2013a. Evaluation of a feeding strategy to reduce greenhouse emissions from dairy farming: The level of analysis matters. Agric. Syst. 121:9-22

Van Middelaar, C. E., C. Cederberg, T. V. Vellinga, H. M. G. Van Der Werf, and I. J. M. De Boer. 2013b. Exploring variability in methods and data sensitivity in carbon footprints of feed ingredients. Int. J. Life Cycle Assess. 18:768-782.

Vellinga, T. V., H. Blonk, M. Marinussen, W. J. van Zeist, and I. J. M. de Boer. 2013. Methodology used in feedprint: A tool quantifying greenhouse gas emissions of feed production and utilization. Wageningen UR Livestock Research, the Netherlands. Accessed Jan 10, 2013. http://edepot.wur.nl/254098.

Vellinga, T. V., and I. E. Hoving. 2011. Maize silage for dairy cows: Mitigation of methane emissions can be offset by land use change. Nutr. Cycl. Agroecosyst. 89:413-426.

Vierde Nederlands Actieprogramma Nitraatrichtlijn. 2009. Vierde Nederlandse Actieprogramma betreffende de Nitraatrichtlijn (2010-2013). Accessed Oct. 3, 2012. http://www.rijksoverheid.nl/ documenten-en-publicaties/rapporten/2009/03/24/vierde-nederlandse-actieprogramma-betreffende-de-nitraatrichtlijn-2010-2013. html.

Wageningen UR. 2008. Quantitative Livestock Farming Information 2007-2008 (KWIN-V, Kwantitatieve Informative Veehouderij 2007-2008). Animal Sciences Group, Wageningen UR, Wageningen, the Netherlands.

Wageningen UR. 2013. Quantitative Livestock Farming Information 2012-2013 (KWIN-V, Kwantitatieve Informative Veehouderij 2012-2013). Livestock Research, Wageningen UR, Wageningen, the Netherlands.

Wall, E., G. Simm, and D. Moran. 2010. Developing breeding schemes to assist mitigation of greenhouse gas emissions. Animal 4:366376.

Zehetmeier, M., J. Baudracco, H. Hoffmann, and A. Heißenhuber. 2012. Does increasing milk yield per cow reduce greenhouse gas emissions? A system approach. Animal 6:154-166.

\section{APPENDIX}

Table A1. Nutritional values of feed ingredients ${ }^{1}$

\begin{tabular}{|c|c|c|c|c|c|c|}
\hline Dietary option & $\begin{array}{c}\mathrm{NE}_{\mathrm{L}}(\mathrm{MJ} / \mathrm{kg} \\
\text { of } \mathrm{DM})\end{array}$ & $\begin{array}{l}\mathrm{DVE}^{2} \\
(\mathrm{~g} / \mathrm{kg} \text { of } \\
\mathrm{DM})\end{array}$ & $\begin{array}{c}\mathrm{OEB}^{3} \\
(\mathrm{~g} / \mathrm{kg} \text { of } \\
\mathrm{DM})\end{array}$ & $\begin{array}{l}\mathrm{N}(\mathrm{g} / \mathrm{kg} \\
\text { of DM) }\end{array}$ & $\begin{array}{l}\mathrm{P}(\mathrm{g} / \mathrm{kg} \\
\text { of DM) }\end{array}$ & $\begin{array}{c}\text { Fill value } \\
(\mathrm{kg} / \mathrm{kg})\end{array}$ \\
\hline \multicolumn{7}{|l|}{ Concentrate } \\
\hline Standard protein & 7.2 & 100 & 5.6 & 24.1 & 4.5 & $0.29-0.72$ \\
\hline Medium protein & 7.2 & 133 & 27.8 & 32.2 & 5.0 & $0.29-0.72$ \\
\hline High protein & 7.2 & 200 & 83.3 & 48.3 & 8.0 & $0.29-0.72$ \\
\hline \multicolumn{7}{|l|}{ Fresh grass } \\
\hline $125 \mathrm{~kg}$ of $\mathrm{N}$ & 6.6 & 94 & 9.3 & 28.0 & 4.1 & 0.93 \\
\hline $175 \mathrm{~kg}$ of $\mathrm{N}$ & 6.7 & 96 & 16.1 & 29.4 & 4.1 & 0.93 \\
\hline $225 \mathrm{~kg}$ of $\mathrm{N}$ & 6.7 & 98 & 23.5 & 30.9 & 4.1 & 0.93 \\
\hline $275 \mathrm{~kg}$ of $\mathrm{N}$ & 6.8 & 99 & 31.2 & 32.4 & 4.1 & 0.93 \\
\hline \multicolumn{7}{|l|}{ Grass silage } \\
\hline $125 \mathrm{~kg}$ of $\mathrm{N}$ & 5.9 & 70 & 22.2 & 25.6 & 4.1 & 1.08 \\
\hline $175 \mathrm{~kg}$ of $\mathrm{N}$ & 5.9 & 71 & 30.6 & 27.4 & 4.1 & 1.08 \\
\hline $225 \mathrm{~kg}$ of $\mathrm{N}$ & 6.0 & 73 & 39.0 & 29.0 & 4.1 & 1.08 \\
\hline $275 \mathrm{~kg}$ of $\mathrm{N}$ & 6.0 & 74 & 47.3 & 30.6 & 4.1 & 1.08 \\
\hline Maize silage & 6.6 & 58 & -36.0 & 13.4 & 1.9 & 1.02 \\
\hline
\end{tabular}

${ }^{1}$ All feed ingredients are available in summer and winter, except for fresh grass (only in summer).

${ }^{2} \mathrm{DVE}=$ true protein digested in the small intestine according to Dutch standards (Tamminga et al., 1994).

${ }^{3} \mathrm{OEB}=$ rumen-degradable protein balance according to Dutch standards (Tamminga et al., 1994).

${ }^{4}$ Fill value per kilogram of feed expressed in kilograms of a standard reference feed (see Jarrige, 1988). The fill value of concentrates increases with an increase in concentrate intake. 
Table A2. Emissions factors for enteric fermentation and production per feed product

\begin{tabular}{|c|c|c|c|}
\hline \multirow[b]{2}{*}{ Feed product } & \multirow[b]{2}{*}{$\begin{array}{l}\text { Enteric fermentation } \\
\left(\mathrm{g} \text { of } \mathrm{CH}_{4} / \mathrm{kg} \text { of } \mathrm{DM}\right)\end{array}$} & \multicolumn{2}{|c|}{$\begin{array}{c}\text { Production }^{2} \\
\left(\mathrm{~g} \text { of } \mathrm{CO}_{2} \text { equivalent } / \mathrm{kg} \text { of } \mathrm{DM}\right)\end{array}$} \\
\hline & & $\begin{array}{l}\text { Excluding } \\
\text { LUC }^{3}\end{array}$ & $\begin{array}{l}\text { Including } \\
\text { LUC }\end{array}$ \\
\hline \multicolumn{4}{|l|}{ Grazed grass } \\
\hline $125 \mathrm{~kg}$ of N/ha & 23.74 & $128-284$ & $313-469$ \\
\hline $175 \mathrm{~kg}$ of $\mathrm{N} / \mathrm{ha}$ & 22.74 & $142-337$ & $309-504$ \\
\hline $225 \mathrm{~kg}$ of $\mathrm{N} / \mathrm{ha}$ & 21.74 & $156-386$ & $311-541$ \\
\hline $275 \mathrm{~kg}$ of $\mathrm{N} / \mathrm{ha}$ & 20.74 & $171-435$ & $316-580$ \\
\hline \multicolumn{4}{|l|}{ Grass silage } \\
\hline $125 \mathrm{~kg}$ of $\mathrm{N} / \mathrm{ha}$ & 22.74 & $153-301$ & $329-477$ \\
\hline $175 \mathrm{~kg}$ of $\mathrm{N} / \mathrm{ha}$ & 21.74 & $164-349$ & $322-507$ \\
\hline $225 \mathrm{~kg}$ of $\mathrm{N} / \mathrm{ha}$ & 20.74 & $175-393$ & $322-540$ \\
\hline $275 \mathrm{~kg}$ of $\mathrm{N} / \mathrm{ha}$ & 19.74 & $187-438$ & $325-575$ \\
\hline Maize silage, home grown & 17.74 & $157-229$ & $251-323$ \\
\hline Maize silage, purchased & 17.74 & 176 & 267 \\
\hline \multicolumn{4}{|l|}{ Concentrate } \\
\hline Standard protein & 20.09 & 724 & 836 \\
\hline Medium protein & 19.55 & 741 & 862 \\
\hline High protein & 19.93 & 774 & 934 \\
\hline
\end{tabular}

${ }^{1}$ Emission factors are based on Vellinga et al. (2013), using a mechanistic model originating from Dijkstra et al. (1992) and updated by Mills et al. (2001) and Bannink et al. (2006).

${ }^{2}$ Emissions from production of home grown grass and maize silage depend on type of fertilizer (organic or synthetic), which is an outcome of the LP model. Emissions per kilogram of DM can vary between the lowest (100\% organic fertilizer) and the highest (100\% synthetic fertilizer) figure. Emissions factors are presented excluding and including emissions from land use change. Including land use change involves an additional emission of $1.43 \mathrm{t}$ of $\mathrm{CO}_{2}$ equivalent/ha due to deforestation worldwide (Audsley et al., 2009). Land use per tonne of DM maize silage is 0.061 ha, and per tonne of DM concentrates is 0.087 (standard protein), 0.094 (medium protein), and 0.125 ha (high protein).

${ }^{3} \mathrm{LUC}=$ land use change.

Table A3. Live weight and amount of edible product per animal, and emission factors per kilogram of edible product related to cows and calves culled from the dairy farm

\begin{tabular}{|c|c|c|c|}
\hline Item & $\begin{array}{l}\text { Live weight }{ }^{1} \\
\text { (kg/animal) }\end{array}$ & $\begin{array}{l}\text { Edible product }{ }^{2} \\
\quad(\mathrm{~kg} / \text { animal })\end{array}$ & $\begin{array}{l}\text { Emission factor }{ }^{3} \\
\text { (kg of } \mathrm{CO}_{2} \text { equivalent } / \mathrm{kg} \\
\text { of edible product) }\end{array}$ \\
\hline Dairy cows & 650 & 264 & 0.4 \\
\hline Heifers & 545 & 221 & 0.4 \\
\hline Young stock, >12 mo & 320 & 130 & 0.4 \\
\hline Calves (white veal) & 225 & 101 & 10.5 \\
\hline
\end{tabular}

${ }^{1}$ Based on Remmelink et al. (2012).

${ }^{2}$ The ratio between edible product and live weight was estimated based on the ratio for beef (0.43; De Vries and De Boer, 2010) and the ratio between live weight and carcass weight for dairy cattle according to Sebek and Temme (2009) and Wageningen UR (2013).

${ }^{3}$ Emissions from transport and slaughtering of dairy cows, heifers, and young stock $>12$ mo were based on Finnish Environmental Institute (2002). Emissions from production of white veal (emissions from feeding, housing, transport, and slaughter) are based on H. Mollenhorst (Wageningen UR, Wageningen, the Netherlands, personal communication, 2013). 